\title{
Radial nerve torsion
}

Figure 1 Ultrasound of radial nerve torsion shows characteristic waist

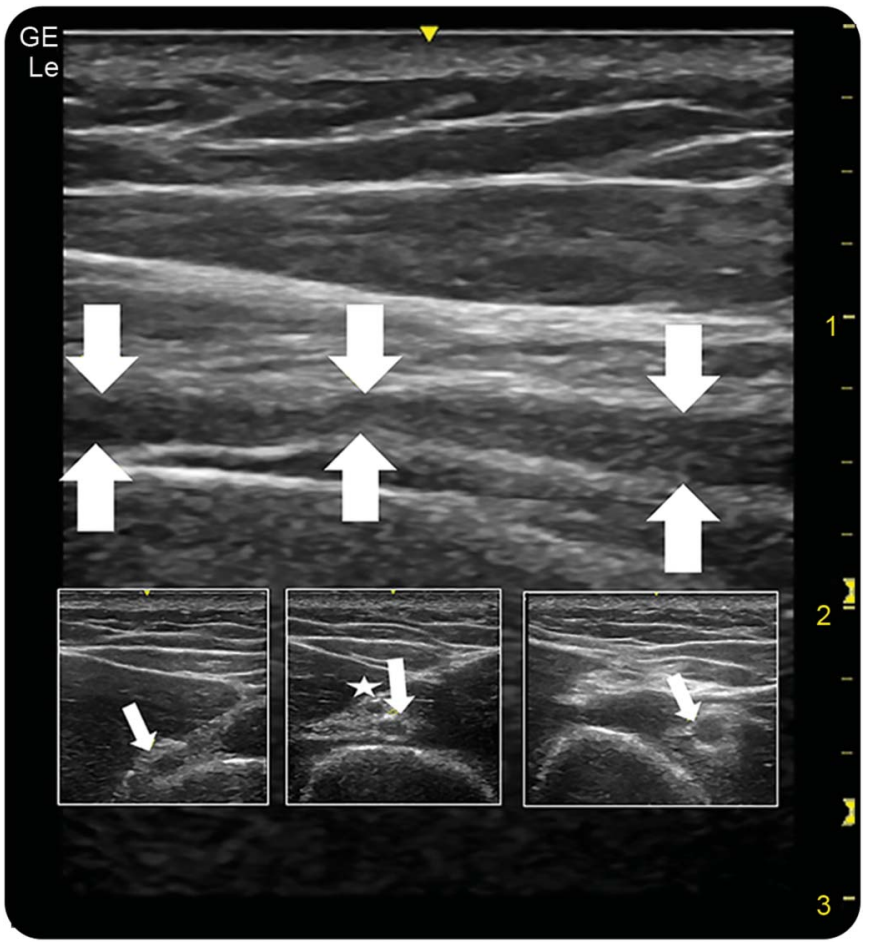

Longitudinal ultrasound image across the spiral groove. Large arrows indicate site of axial imaging shown below in the smaller images. Smaller arrows point to the radial nerve. $A$ is at entry $B$ midsection and $C$ after exit from spiral groove. The star lies above the deep brachial artery.

Peripheral nerve torsion is increasingly recognized due to the widespread availability of nerve ultrasound imaging. ${ }^{1,2}$ A 31-year-old man presented with acute onset complete left wrist drop after prolonged sleeping on his outwardly rotated arm. There was severe conduction block across the spiral groove and nerve ultrasound showed 2 areas with increased diameter (figure 1). On operation, there was radial nerve trunk torsion at the level of the intermuscular septum just distal to the spiral groove (figure 2). Two months after operation there was no improvement of the complete wrist drop.

This case illustrates the ultrasound imaging features of radial nerve torsion. The mechanism is thought to initiate with focal nerve inflammation resulting in loss of elasticity, leading to ratcheting of rotational forces exerted on the nerve.

Duminda Samarawickrama, MBBS, Aravinda K. Therimadasamy, BSc, Sandeep J. Sebastin, MBBS, Einar P. Wilder-Smith, MD

From National University Hospital (D.S., A.K.T., S.J.S.) and Yong Loo Lin School of Medicine (E.W.-S.), National University Singapore.

Author contributions: Dr. Duminda, Dr. Sebastin, and A.K. Therimadasamy helped with the compilation of the case. Dr. Sebastin performed the radial nerve surgery. Dr. Wilder-Smith diagnosed the radial neuropathy, performed ultrasound, and formulated the final manuscript.

Study funding: No targeted funding reported.

Disclosure: The authors report no disclosures relevant to the manuscript. Go to Neurology.org for full disclosures.

Correspondence to Dr. Wilder-Smith: mdcwse@nus.edu.sg 
Figure 2 Radial nerve torsion at operation at the mid-level of the spiral groove

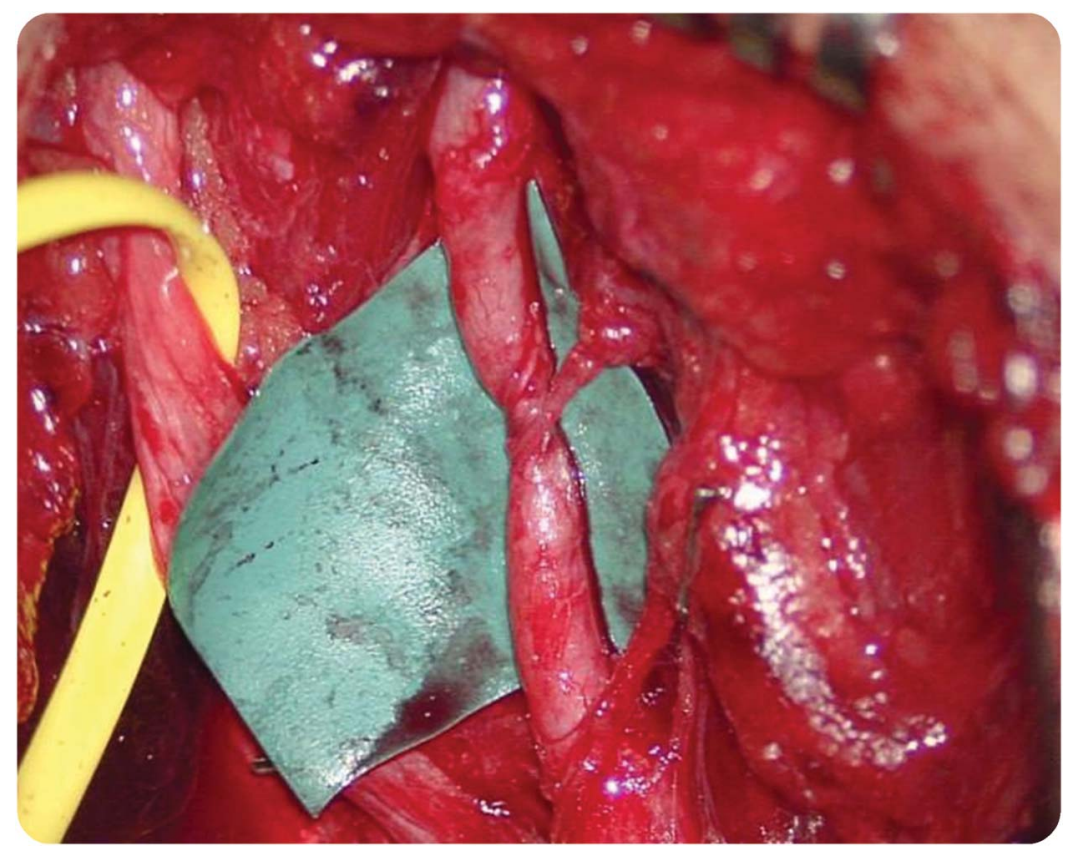

Note the radial nerve waist.

1. Fernandez E, Di Rienzo A, Marchese E, Massimi L, Lauretti L, Pallini R. Radial nerve palsy caused by spontaneously occurring nerve torsion: case report. J Neurosurg 2001;94:627-629.

2. Guerra WK, Schroeder HW. Peripheral nerve palsy by torsional nerve injury. Neurosurgery 2011;68:1018-1024.

\section{Visit the Neurology ${ }^{\circledR}$ Web Site at Neurology.org}

- Enhanced navigation format

- Increased search capability

- Highlighted articles

- Detailed podcast descriptions

- RSS Feeds of current issue and podcasts

- Personal folders for articles and searches

- Mobile device download link

- AAN Web page links

- Links to Neurology Now ${ }^{\circledR}$, Neurology Today ${ }^{\circledR}$, and Continuum ${ }^{\circledR}$

- Resident \& Fellow subsite

(1) Find Neurology ${ }^{\circledR}$ on Facebook: http://tinyurl.com/neurologyfan

twitter Follow Neurology ${ }^{\circledR}$ on Twitter: https://twitter.com/GreenJournal 


\section{Neurology}

\section{Radial nerve torsion}

Duminda Samarawickrama, Aravinda K. Therimadasamy, Sandeep J. Sebastin, et al. Neurology 2016;86;1559-1560

DOI 10.1212/WNL.0000000000002597

\section{This information is current as of April 18, 2016}

\section{Updated Information \&} Services

References

Subspecialty Collections

Permissions \& Licensing

Reprints including high resolution figures, can be found at: http://n.neurology.org/content/86/16/1559.full

This article cites 2 articles, 0 of which you can access for free at: http://n.neurology.org/content/86/16/1559.full\#ref-list-1

This article, along with others on similar topics, appears in the following collection(s):

Peripheral nerve trauma

http://n.neurology.org/cgi/collection/peripheral_nerve_trauma Ultrasound

http://n.neurology.org/cgi/collection/ultrasound

Information about reproducing this article in parts (figures,tables) or in its entirety can be found online at:

http://www.neurology.org/about/about_the_journal\#permissions

Information about ordering reprints can be found online:

http://n.neurology.org/subscribers/advertise

Neurology ${ }^{\circledR}$ is the official journal of the American Academy of Neurology. Published continuously since 1951, it is now a weekly with 48 issues per year. Copyright @ 2016 American Academy of Neurology. All rights reserved. Print ISSN: 0028-3878. Online ISSN: 1526-632X.

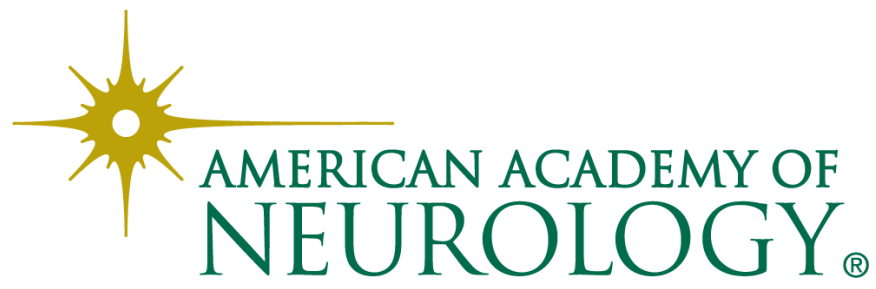

